\title{
NOMENCLATURE OF ABNORMAL HAEMOGLOBINS
}

In the course of the VIIIth International Congress of Haematology in September, 1960, in Tokyo, Japan, 44 members met to discuss the nomenclature of the human haemoglobins. This field is expanding so rapidly that it is not possible even at an international congress to obtain a full representation of all disciplines and groups of workers. The absence of several distinguished investigators in this field was acutely felt. Nevertheless the VIIIth International Congress of Haematology was considered the best possible occasion for such a gathering. The following recommendations are being sent to appropriate journals so that any of the distinguished investigators not present will be able to criticize them in public.

(1) The recommendations on nomenclature made at the Symposium on Abnormal Haemoglobins in Istanbul, 1958, and published in 1959 (Council for International Organizations of Medical Sciences, 1959), are endorsed and the letters $\mathbf{A}-\mathbf{N}$ (with the exception of $B$ ), and $S$ are recognized as naming haemoglobins as there defined.

(2) The description of the variants of haemoglobin $\mathbf{M}$ as $\mathbf{M}_{\mathbf{B}}, \mathbf{M}_{\mathbf{M}}, \mathbf{M}_{\mathbf{S}}$ (from Boston, Milwaukee, and Saskatoon respectively) is accepted (Gerald, 1958 ; Pisciotta, Ebbe, and Hinz, 1959), and it is suggested that new haemoglobins $M$ are described with fully subscripted names until they have been shown to differ from these three, when they should be given subscript initials ( $\mathbf{M}_{\text {wate }}$, possibly later $\mathbf{M}_{\mathbf{I}}$ ).

(3) The letters $O, P$, and $Q$ are being allotted to the haemoglobins described under these letters (Lie-Injo Luan Eng and Sadono, 1958 ; Schneider and Haggard, 1958 ; Vella, Wells, Ager, and Lehmann, 1958).

(4) Until the next meeting of the International Congress the letters $R-Z$ (excepting $S$ ) should not be allotted to new abnormal haemoglobins but these should be given names of localities. It should be left to the individual workers to choose the most meaningful name from the origin of the propositus, or the laboratory, hospital, town, or district where the haemoglobin was found. A new name should not be allotted in this way unless it has been ascertained that the haemoglobin to be named is different from all those adequately described in the literature.

(5) Of the two designations of the haemoglobin $\mathbf{A}_{2}$ variant: $\mathbf{A}_{2}{ }^{\prime}$ and $\mathbf{B}_{2}$ (Kunkel, Ceppelini, Dunn, and Firsheim, 1959), the first is found more acceptable. If a third variant should be found it should be named $\mathrm{A}_{2}$ " and not $\mathrm{C}_{2}$.

(6) The names of the three known peptide chains of human haemoglobin are $\alpha, \beta$, and $\gamma$ (Schroeder, 1959), and it is suggested that the normal chains should be designated in that way, i.e., not $\alpha^{\mathrm{A}}$ or $\alpha^{\mathrm{F}}, \beta^{\mathrm{A}}$ and $\gamma^{\mathrm{F}}$. The genetic superscript for the normal gene product + $\left(\alpha^{+}, \beta^{+}, \gamma^{+}\right)$will not be used as it implies to the chemist a positive charge.

(7) The expressions $\beta_{4}$ for $\mathbf{H}$ and $\gamma_{4}$ for Bart's may be used when their identity is fully accepted. However, until the next meeting of the International Congress the traditional names should be mentioned at least once in each publication.

(8) The present custom to describe an abnormal chain by adding the name of the appropriate abnormal haemoglobin in superscript should be maintained $\left(\mathrm{S}=\alpha_{2} \beta_{2} \mathrm{~S}\right.$; Hopkins- $2=\alpha_{2}^{\text {Hopkins-2 }} \beta_{2}$ ).

(9) A polypeptide chain should not be designated with a new small Greek letter (such as $\delta, \epsilon$, etc.) until chemical evidence for complete separate identity from the $\alpha, \beta$, and $\gamma$ chains (such as exists between these chains themselves) has been established, genetic differences notwithstanding.

(10) It is expected that the analysis of the aminoacid sequences in the globin molecule will eventually be followed by a precise chemical nomenclature. Meanwhile if a haemoglobin has been identified by the usual methods of electrophoresis, chromatography, spectroscopy, alkali denaturation, cold denaturation, and solubility tests, it should be described by the accepted capital letter as hitherto (S, C, D, G, E, etc.) as recommended by the working party meeting at the VIth International Congress, Boston, 1956 (Lehmann, 1957). If comparison has been made on the same lines and with the same completeness with a haemoglobin carrying the name of a locality, that name should be applied. If the abnormal chain is identified this should be indicated by a subscript, for example, $D_{\alpha}, D_{\beta}$, and until the full identity by examining the amino-acid sequences has been established this subscript should be followed by a declaration of origin ( $D_{\beta}$ Los Angeles, $G_{a}$ Ibadan). This implies that $D \gamma$ will have to be renamed $D_{\beta}$ Punjab. If two or more of such haemoglobins are then found identical by analysis of the amino-acid sequences, only the name of the haemoglobin which was first discovered and fully defined by the conventional methods should be retained. For example, if $\mathbf{G}_{a}$ Ibadan and $\mathbf{G}_{a \text { Azuakoli }}$ are found to be identical regardless of which the amino-acid sequence has been fully examined first $\mathbf{G}_{a}$ Ibadan should be the remaining name. However, until the next meeting of the International Congress the alternative names should be mentioned at least once in each publication.

(11) No generally acceptable name was agreed upon for the familial condition in which haemoglobin $F$ persists into adult life without morphological changes 
of the red cells and without anaemia. The term nonmicrocythaemic thalassaemia was considered not specific enough as it might equally apply to the familial condition where haemoglobin $\mathbf{A}_{2}$ is raised without associated morphological changes. If the expression "high F gene" is used this should be done with reservation and only provisionally until further knowledge allows better terminology.

(12) If several haemoglobins are present the phenotype should be designated by listing the haemoglobins in order of decreasing concentration regardless of genetic considerations (sickle-cell trait $=$ AS, sicklecell anaemia $=\mathrm{SF}$, sickle-cell thalassaemia $=\mathrm{SAF}$, or SFA, etc.,).

\section{REFERENCES}

Council for International Organizations of Medical Sciences (1959). Abnormal Haemoglobins, p. 387, ed. J. H. P. Jonxis and J. F. Delafresnaye. Blackwell, Oxford.

Gerald, P. S. (1958). Blood, 13, 936

Kunkel, H. G., Ceppelini, R., Dunn, L. C., and Firsheim, L. (1959). Quoted by Ceppelini, R., in Discussion, Ciba Foundation Sym posium, Biochemistry of Human Genetics, p. 134, ed. G. E. W. Wolstenholme and C. M. O'Connor. Churchill, London.

Lehmann, H. (1957). Blood, 12, 90.

Lie-Injo Luan Eng, and Sadono (1958). Brit. med. J., 1, 1461.

Pisciotta, A. V., Ebbe, S. N., and Hinz, J. E. (1959). J. Lab. clin. Med., 54, 73.

Schneider, R. G., and Haggard, M. E. (1958). Nature (Lond.), 182 322.

Schroeder, W. A. (1959). Fortschr. Chem. org. Naturst. (Progr. Chem. org. natur. Prod.), $17,322$.

Vella, F., Wells, R. H. C., Ager, J. A. M., and Lehmann, H.(1958). Brit. med. J., 1, 752.

\section{Association of Clinical Pathologists Broadsheets}

The following broadsheets (new series) are published by the Association of Clinical Pathologists. They may be obtained from Dr. F. Hampson, Department of Pathology, Royal Berkshire Hospital, Reading, price 1s. each.

\begin{tabular}{|c|c|c|c|}
\hline No. & Title & Date & Author \\
\hline 1 & $\begin{array}{c}\text { The Disc Technique for the Rapid Determination of Bacterial Sensitivity to } \\
\text { Antibiotics } \quad \ldots \\
.\end{array}$ & 1952 & R. W. Fairbrother \\
\hline 2 & Determination of Sensitivity of $M$. tuberculosis to Streptomycin .. & 1952 & R. L. Vollum \\
\hline 3 & $\begin{array}{l}\text { The Detection of Barbiturates in Blood, Cerebrospinal Fluid, Urine, and Stomact } \\
\text { Contents }\end{array}$ & & I C Nickolls \\
\hline 4 & $\begin{array}{llllll}\text { Contents } & \| \\
\text { The Estimation of Carbon Monoxide in Blood } & \ldots & \ldots & \ldots & \ldots & \\
.\end{array}$ & $\begin{array}{l}1953 \\
1953\end{array}$ & $\begin{array}{l}\text { L. C. Nickolls } \\
\text { D. A. Stanley }\end{array}$ \\
\hline 5 & The Identification of Reducing Substances in Urine by Partition Chromatography & & \\
\hline 6 & 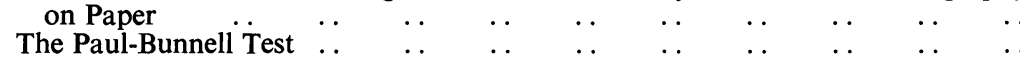 & 1953 & $\begin{array}{l}\text { G. B. Manning } \\
\text { R. H. A. Swain }\end{array}$ \\
\hline 7 & The Papanicolaou Technique for the Detection of Malignant Cells in Sputum . & 1955 & $\begin{array}{l}\text { K. H. A. Swain } \\
\text { F. Hampson }\end{array}$ \\
\hline 8 & $\begin{array}{l}\text { Investigation of Haemorrhagic States, with Special Reference to Defects } 0 \\
\text { Coagulation of the Blood } \ldots \\
.\end{array}$ & 1955 & E. K. Blackburn \\
\hline 9 & 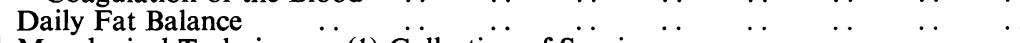 & 1956 & A. C. Frazer \\
\hline 10 & Mycological Techniques: (1) Collection of Specimens & 1956 & R. W. Riddell \\
\hline 11 & Mycological Techniques: (2) Cultural Isolation $\quad$. & 1956 & R. W. Riddell \\
\hline 12 & 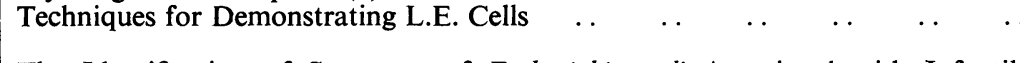 & 1956 & $\begin{array}{l}\text { J. V. Dacie and } \\
\text { L. S. Sacker }\end{array}$ \\
\hline 13 & $\begin{array}{c}\text { The Identification of Serotypes of Escherichia coli Associated with Infantil } \\
\text { Gastro-enteritis }\end{array}$ & 1956 & \\
\hline 14 & The Determination of Serum Iron and Serum Unsaturated Iron-binding Capacit & & Arthur Jordan \\
\hline 15 & 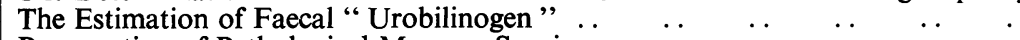 & 1957 & C. H. Gray \\
\hline 16 & Preservation of Pathological Museum Specimens & 1957 & L. W. Proger \\
\hline 17 & Cultural Diagnosis of Whooping-cough $\quad$. & 1957 & B. W. Lacey \\
\hline 18 & The Rose-Waaler Test $\quad \begin{array}{lllll} & \ldots & & \end{array}$ & 1957 & C. L. Greenbury \\
\hline 19 & The Laboratory Diagnosis of Fibrinogen Deficiency & 1958 & R. M. Hardisty \\
\hline $\begin{array}{l}20 \\
21\end{array}$ & Investigation of Porphyrin/Porphyria $\begin{array}{llllll} & \cdots & \cdots & \ldots & \cdots & \cdots\end{array}$ & 1958 & C. Rimington \\
\hline 21 & $\begin{array}{l}\text { Quantitative Determination of Porphobilinogen and Porphyrins in Urine an } \\
\text { Faeces .. }\end{array}$ & 1958 & mingto \\
\hline 22 & 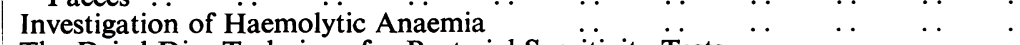 & 1959 & \\
\hline 23 & The Dried Disc Technique for Bacterial Sensitivity Tests .. & 1959 & $\begin{array}{l}\text { R. W. Fairbrother } \\
\text { and J. C. Sherris }\end{array}$ \\
\hline $\begin{array}{l}24 \\
25\end{array}$ & $\begin{array}{l}\text { Safe Handling of Radioactive Tissues in the Laboratory and Post-mortem Roon } \\
\text { Titration of Antistreptolysin } \mathrm{O} \\
\end{array}$ & $\begin{array}{l}1959 \\
1959\end{array}$ & $\begin{array}{l}\text { R. C. Curran } \\
\text { H. Gooder and } \\
\text { R. E. O. Willians }\end{array}$ \\
\hline $\begin{array}{l}26 \\
27\end{array}$ & $\begin{array}{l}\text { The Periodic Acid-Schiff Reaction } \ldots \text {... } \ldots \\
\text { The Laboratory Detection of Abnormal Haemoglobins }\end{array}$ & $\begin{array}{l}1959 \\
1959\end{array}$ & $\begin{array}{l}\text { A. G. E. Pearse } \\
\text { H. Lehmann }\end{array}$ \\
\hline
\end{tabular}

